\title{
Exploring the Impact of Submarine Saturation on Strategic Stability in South Asia
}

\author{
Author: Kupriyanov, Alexey
}

To cite this article: Kupriyanov, A. (2022). Exploring the Impact of Submarine Saturation on Strategic Stability in South Asia. National Security Journal. Published 27 February 2022. doi:10.36878/nsj20220227.08

To link to this article: $\underline{\text { https://doi.org/10.36878/nsj20220227.08 }}$

View CrossRef data: https://search.crossref.org/?q=10.36878\%2Fnsj20220227.08 


\title{
EXPLORING THE IMPACT OF SUBMARINE SATURATION ON STRATEGIC STABILITY IN SOUTH ASIA
}

\begin{abstract}
Alexey Kupriyanov ${ }^{1}$
Due to the growing rivalry between local and external actors, the Indian Ocean region is increasingly the site of an underwater Cold War. India and Pakistan are actively developing their submarines, contributing to regional maritime saturation. While India plans to increase the number of conventional vessels and nuclear-powered submarines armed with nuclear-capable ballistic missiles, Pakistan is working on launching nuclear-capable cruise missiles from diesel-electric submarines. This maritime saturation leads to the emergence of new threats and the revitalisation of old ones. The danger of accidental collisions between nuclear-powered submarines and diesel submarines, in some cases both with nuclear weapons on board, is increasing. Mutual misunderstanding of strategic imperatives and mistrust can lead to accidental conflicts, and incidents on board nuclear submarines. This essay argues that it is necessary to raise awareness of these challenges and of strategic cultures in the region to prevent incidents with nuclear weapons.
\end{abstract}

Key Words: Indian Ocean, People’s Liberation Army Navy, Indian Navy, Pakistan Navy, submarine

\section{Introduction}

The impact of nuclear-powered ballistic missile submarines (SSBNs) and their secondstrike capabilities on strategic stability in South Asia has been considered in a variety of previous studies. ${ }^{1}$ While containing valuable insights, these papers are largely outdated amid the rapidly changing situation in the Indian Ocean and South Asia. The beginning of the naval strategic race between the United States and China, the expansion of the

1 Dr Alexey Kupriyanov is a Senior Research Fellow in the Primakov National Research Institute of World Economy and International Relations within the Russian Academy of Sciences. 
sphere of Chinese interests into the Indian Ocean region, the strengthening of the China-Pakistan strategic partnership and the growing rivalry between India and China are transforming the Indian Ocean region into a space that is literally teeming with nuclear and conventional submarines of potential participants in an underwater Cold War.

Furthermore, the increased presence of surface vessels for anti-submarine warfare, unmanned underwater vehicles and underwater acoustic sensor networks also adds to the complexity of this rapidly changing maritime environment. ${ }^{2}$ These trends completely change the picture of what is occurring in the region. ${ }^{3}$ This essay will explore the positive and negative implications for strategic stability of saturating the Indian Ocean region with SSBNs and nuclear-capable diesel-electric submarines, concluding with some recommendations to address these conditions.

\section{SSBNs and Nuclear-Capable Diesel-Electric Submarines in South Asia}

The manner in which submarines have been introduced into South Asia has been unique. India is now the only country in the world to have acquired submarines following its introduction of aircraft carriers. ${ }^{4}$ This unusual situation occurred due to the fact that the United Kingdom, for whose help India hoped, for a long time refused to sell submarines to the latter. This was based on two assumptions, namely that the Indian sailors would be insufficiently trained to operate them, and that India would not require submarines as an offensive weapon. Thus, the issue of owning submarines became a matter of self-respect for the Indian Navy. As Vice Admiral G.M. Hiranandani writes, the Indian Navy 'impressed on the Government that every Navy worth its name had to have submarines.' As such, India received its first submarines from the Soviet Union, but also worked on its own related projects. This work first began in 1970, followed by the launch of India's Advanced Technology Vessel (ATV) program in 1984, which included the creation of high-speed deep-diving nuclear-powered attack submarines. ${ }^{6}$ This is significant because this program became the starting point for the development of Indian SSBNs.

By 1999, India introduced its draft nuclear doctrine, which included the concept of second strike and contained the mention that India would not use nuclear weapons first. ${ }^{7}$ With the introduction of India's Arihant-class of SSBNs, designed with Russian assistance, India's ability to deliver on its second-strike capabilities has increased markedly. ${ }^{8}$ Among these, the INS Arihant, commissioned in August 2016, is reportedly able to carry 12 K-15 Sagarika submarine-launched ballistic missiles (SLBMs) with ranges of 750 kilometres. ${ }^{9}$ The second of these submarines, the INS Arighat, is due to be commissioned in 2021 and was built under India's ATV program. Two more submarines of this class are anticipated to be launched in the coming years. ${ }^{10}$ Each of them is scheduled to carry eight K-4 Shaurya SLBMs, which have an estimated range of 3,500 kilometres. ${ }^{11}$ 
The K-5 and K-6 SLBMs are reportedly under development by India's Defense Research and Development Organisation to equip India's next generation of SSBNs, such as S5class submarines. ${ }^{12}$

In light of these enhanced deployments and second-strike capabilities, it is important to consider the potential increase in the number of SSBNs in the context of an overall expansion of Indian submarines. India is now actively developing the submarine arm of its Navy. To this end, it has one SSBN and 15 non-nuclear submarines and is going to expand to include a total of 18 non-nuclear submarines, adding three Kalvari-class submarines and four SSBNs. ${ }^{13}$ This expansion may be attributed to four central factors. First, India needs to update the submarine arm of its Navy, since most of its submarines are 25-35 years old. Six of them are undergoing a mid-life refit and at least the same number will require it over the next 10 years. ${ }^{14}$ Second, as discussed below, the submarine arm of Pakistan's Navy is also strengthening, which is causing India concern.

Third, due to budgetary constraints, India's Chief of Defense Staff has advised the Indian Navy to focus on submarines as a cheaper anti-access/area-denial (A2/AD) weapon, as opposed to more capital-intensive naval vessels like aircraft carriers. ${ }^{15}$ Fourth, India sees the potential threat of China's increasing presence in the region changing the strategic balance. ${ }^{16}$ For these reasons, it is clear that attack submarines, which India now lacks, will play a greater role in India's naval strategy for the foreseeable future. At the same time, due to the increasing capabilities of Pakistan and due to the growing confrontation with China and its enhanced nuclear potential, India is likely to increase the number of its SSBNs.

On Pakistan, the case is even more intriguing. It does not have SSBNs, but it has nuclear-capable diesel-electric submarines, which can reportedly carry the Babur-III nuclear-capable sea-launched cruise missile (SLCM) ${ }^{17}$ Pakistan's potential to deploy a SLCM is of importance because it enables Pakistan, without building expensive SSBNs, to acquire a naval component of the nuclear triad. This option would constitute the core of Pakistan's Strategic Naval Command, as it would reportedly be able to launch its Babur-III from one of three types of Agosta 90B-class submarines, namely the PNS/M Khalid, PNS/M Saad and PNS/M Hamza. ${ }^{18}$

Additionally, it is anticipated that China will supply eight more upgraded Type 039B diesel-electric submarines, which can also carry SLCMs. ${ }^{19}$ There also exists the potential that Pakistan, with Chinese assistance, will either develop or build SSBNs, or receive them on lease. ${ }^{20}$ The likelihood of this depends in part on the future trajectory of India-China relations and whether they worsen over time. It further relies on Pakistan's ability to pay for these submarines. However, it seems highly likely that China, if necessary, will sponsor their acquisition. In this case, Pakistan will strengthen the naval component of the nuclear triad, which will improve its position in its competition with India and will most likely trigger a new race of nuclear weapons at sea. 
For Pakistan, there are challenges in deploying both its nuclear-capable diesel-electric submarines and possible SSBNs in the future. On the one hand, it is unlikely that India will be the first to use nuclear weapons against Pakistan in the event of a conflict, given that India already retains strategic depth and conventional superiority. On the other hand, Pakistan's nuclear-capable submarines may deprive India of the temptation to reconsider its no-first-use (NFU) posture and to launch targeted strikes on launchers and nuclear weapons storage facilities, ensuring that Pakistan will not have nuclear weapons at its disposal.

\section{Saturation at Sea with SSBNs and Nuclear-Capable Diesel-Electric Submarines}

There are a variety of challenges elicited by the growing saturation of submarines in the Indian Ocean region. Among these, three stand out. The first key challenge is that India's and Pakistan's nuclear-armed submarines operate in a common maritime space. On land, the likelihood that a military vehicle equipped with nuclear weapons will directly collide with an adversary's military vehicle, thereby triggering a nuclear accident or escalation, is extremely small. At sea, a collision of two submarines with nuclear weapons on board may become a reality, particularly after the reported participationalbeit without nuclear missiles on board-of the nuclear-powered INS Arihant and INS Chakra in Indian Navy manoeuvres surrounding the 2019 Pulwama and Balakot tensions in Kashmir. ${ }^{21}$ Although the patrol areas of Indian and Pakistani nuclear-armed submarines are obviously different, it is possible for a navigational error or unforeseen complications to force a ship to change its patrol area. The presence of submarines from third countries complicates the situation even more. At the same time, even a clash of hunter-killer submarines and nuclear submarines poses a serious threat.

Fortunately, thus far, collisions of nuclear-powered ships and ships with nuclear weapons on board, even during heightened tensions between the Union of Soviet Socialist Republics (USSR) and the United States, have not led to serious consequences such as the start of a nuclear war. ${ }^{22}$ In and of themselves, the deployment of SLBMs and SLCMs on SSBNs and diesel-electric submarines contribute to strategic stability, since they strengthen a country's second-strike capability and reduce the allure of a first strike for its adversaries. However, it must be borne in mind that the weapons on these submarines are operationally deployed and ready-to-use. Further, there has been speculation that given the vulnerabilities of command and control and undersea communications on submarines, such platforms may instead reduce strategic stability.

On submarines, in particular SSBNs, the level of delegation can be much higher than on surface ships. However, this only means that it is necessary to approach the selection of senior officers more responsibly. ${ }^{23}$ In the Indian Ocean region, the limited theatre of operations makes it possible to establish under certain conditions a stable connection with the submarine on alert. For example, Pakistan has deployed a very low frequency 
(VLF) facility at PNS Hameed naval base near Karachi, which will help maintain constant communication with submarines in the Arabian Sea. ${ }^{24}$ Such measures can mitigate potential issues of collision. At the same time, the limited theatre of operations and its saturation with submarines can lead to problems with stable communications.

The second key challenge stems from misinterpreting the intentions of a real or perceived adversary. This difficulty is universal in that each country does so through the prism of its own knowledge base, perceptions and strategic culture. Nevertheless, the main task becomes how to reduce this misinterpretation as much as possible. In the case of India, its leadership and strategists tend to view Chinese aggression as part of any action by the latter in the Indian Ocean region. ${ }^{25}$ This has led to an Indian narrative of China of seeking to encircle and strangle India with a so-called 'String of Pearls. ${ }^{26}$

In a number of cases, incidents cited to support such claims have alternate explanations. As they pertain to the peak of Chinese submarine presence in the Indian Ocean region in 2017, China justified these activities as essential to its support for anti-piracy patrols off the coast of Somalia. ${ }^{27}$ In India, this caused understandable scepticism, since SSBNs are not suited to combating pirates in the Gulf of Aden. ${ }^{28}$ Since 2017, the number of visits by Chinese submarines to the Indian Ocean region has sharply decreased, but the rhetoric of Indian experts has not changed and allegations of China increasing its presence in the region remain. ${ }^{29}$

While China's military presence is indeed growing, this remains largely a function of its efforts to strengthen its ties with smaller regional navies, such as the ones of Myanmar, Sri Lanka, Tanzania, and Thailand, among others. In the future, this situation may accelerate, due to the build-up of US influence in the region, the need to protect Chinese routes or a change in India's foreign policy and its rapprochement with the United States. It could be argued, however, that India is not standing still in the face of these trends. India's pursuit of parity with China on a tight budget will contribute to an increase in its number of submarines and an ever-growing suspicion of China's motives. This combination will lead to an atmosphere of anxiety and the interpretation of its actions as threatening, which can lead to serious errors and misinterpretation when crises arise.

A third key challenge is the potential for radiological incidents that are not directly related to military events, but can be caused by naval reactors malfunctions, operators faults and the problems with guarding military bases and docked submarines. While their consequences are potentially less damaging than those from erroneous interpretation of manoeuvres by an adversary's SSBN and nuclear-capable diesel-electric submarines, they can still result in casualties and nuclear risks. Incidents of this kind occurred repeatedly during the Cold War, and there is no reason to believe that there will be fewer of them in the event of a new underwater Cold War. ${ }^{30}$ 


\section{Conclusion}

Confronting the growing numbers of SSBNs and nuclear-capable diesel-electric submarines in the Indian Ocean region, there are a range of challenges that must be acknowledged and addressed. Among these, the role of external forces will continue to grow and to have an impact, China and the United States above all. ${ }^{31}$ As a result, their presence in South Asia has a strong potential for rivalry and escalation. When combined with India's lack of trust for China, any emergence of Chinese submarines in the region will lead to further destabilisation.

While it could be argued that during the Cold War between the USSR and the United States and their allies, the presence of both Soviet and US navies in the Indian Ocean region did not lead to this instability. Instead, this was a secondary theatre of operations. Now that the Indian Ocean region is part of the US Indo-Pacific strategy, the likelihood of China-United States confrontation grows. ${ }^{32}$ As a result, any presence of US or Chinese naval vessels in this region has the potential for instability. By contrast, third-party countries not involved in the new Cold War, such as Russia or the European Union could stabilise the situation. These forces are not interested in confrontation with each other, much less with local actors, suggesting that they could play a positive role in crisis mitigation.

As South Asia's maritime environment is increasingly saturated with SSBNs and nuclear-capable diesel-electric submarines, it is imperative that answers are found to at least some of the threats identified above. And there are some potential steps for doing so. First, measures to prevent collisions at sea of submarines with nuclear weapons on board could be introduced, such as the definition of patrol areas. Second, measures to increase trust and understanding between countries whose submarines patrol the Indian Ocean region must be discussed. A more complete understanding of each other's strategic culture and intentions will avoid misinterpreting the other side's actions. The third threat associated with possible reactor accidents and operator errors cannot be eliminated until the need for nuclear deterrence disappears. As this is the least likely of the three, setting the groundwork on controls and cultures will contribute to crisis management and mitigation in the increasingly submarine-saturated Indian Ocean region. 
1 A second-strike capability is an assured ability to respond to a nuclear attack with nuclear retaliation against the attacker. Strategic stability can be defined as the lack of incentives for either side to launch a first nuclear strike. Dvorkin, Vladimir, 'Preserving Strategic Stability Amid U.S.-Russian Confrontation', Carnegie Moscow Center, 8 Feb. 2019, <https://carnegiemoscow.org/2019/02/08/preserving-strategicstability-amid-u.s.-russian-confrontation-pub-78319>; Dittmer, Lowell, South Asia's Nuclear Security Dilemma: India, Pakistan, and China, (New York: Routledge, 2005); Rajagopalan, Rajesh and Mishra, Atul, Nuclear South Asia: Keywords and Concepts, (Delhi: Routledge, 2014); and Krepon, Michael, Nuclear Risk Reduction in South Asia, (New York: Palgrave MacMillan, 2004).

2 Akhtar, Aqueel and Ullah, Sufian, (2021): India's sea-based nuclear forces and strategic stability in South Asia, Australian Journal of Maritime \& Ocean Affairs, vol. 1, no. 1, 2021, pp. 1-15; and Amit Ray. Tracing the Undersea Dragon: Chinese SSBN Programme and the Indo-Pacific, (Delhi: Routledge, 2021).

3 Akhtar, Aqueel and Ullah, Sufian, (2021): India's sea-based nuclear forces and strategic stability in South Asia, Australian Journal of Maritime \& Ocean Affairs, vol. 1, no. 1, 2021, pp. 1-15; and Amit Ray. Tracing the Undersea Dragon: Chinese SSBN Programme and the Indo-Pacific, (Delhi: Routledge, 2021).

4 The first Indian aircraft carrier Vikrant was commissioned in 1961, the first Indian submarine Kalvari was commissioned in 1967.

5 Hiranandani, G.M., Transition to Triumph: History of the Indian Navy, 1965-1975, (Delhi: Lancer Publishers, 2012).

6 Revi, A.P., 'India's Nuclear Submarine Programme', Indian Defence Review, vol. 31, no. 1, Jan.Mar. 2016, <http://www.indiandefencereview.com/news/indias-nuclear-submarine-programme>.

7 Arms Control Association, 'India's Draft Nuclear Doctrine,' $<$ https://www.armscontrol.org/ act/1999-07/indias-draft-nuclear-doctrine>, accessed on 20 Oct. 2021.

8 Naval Technology, 'Arihant Class Submarine', https://www.naval-technology.com/projects/ arihant-class>, accessed on 20 Oct. 2021; Khan, M. Shamsur Rabb, 'The Strategic Significance of Arihant', Institute of Peace and Conflict Studies, 31 Aug. 2009, <http://www.ipcs.org/comm_select. php? articleNo $=2960>$.

9 Peri, Dinakar, 'India successfully test-fires 3,500-km range submarine-launched ballistic missile K-4', The Hindu, 19 Jan. 2020, <https://www.thehindu.com/news/national/india-successfully-test-fires3500-km-k-4-slbm/article30601739.ece>.

10 Pubby, Manu, 'India's Rs 1.2 lakh crore nuclear submarine project closer to realisation', The Economic Times, 21 Feb. 2020, <https://economictimes.indiatimes.com/news/defence/indias-rs-1-2-1-crn-submarine-project-closer-to-realisation/articleshow/74234776.cms>.

11 Panda, Ankit, 'India Tests K-4 Submarine-Launched Missile, Pushing Its Sea-Based Deterrent Forward', The Diplomat, 21 Jan. 2020, <https:/thediplomat.com/2020/01/india-tests-k-4-submarinelaunched-missile-pushing-its-sea-based-deterrent-forward $>$.

12 Unnithan, Sandeep, 'From India Today magazine: A peek into India's top secret and costliest defence project, nuclear submarines', India Today, 10 Dec. 2017, <https://www.indiatoday.in/ magazine/the-big-story/story/20171218-india-ballistic-missile-submarine-k-6-submarine-launcheddrdo-1102085-2017-12-10>.

13 Unnithan, Pandeep, 'From India Today magazine: A peek into India's top secret and costliest defence project, nuclear submarines', India Today, 10 Dec. 2017, <https://www.indiatoday.in/ magazine/the-big-story/story/20171218-india-ballistic-missile-submarine-k-6-submarine-launcheddrdo-1102085-2017-12-10>; Unnithan, Sandeep, 'Why India could be leasing a second nuclear powered attack submarine from Russia', India Today, 4 Sep. 2021, <https://www.indiatoday.in/ india-today-insight/story/why-india-is-leasing-a-second-nuclear-powered-attack-submarine-fromrussia-1849277-2021-09-04>; Times Now News, 'Indian Navy's fifth Scorpene class submarine 'Vagir' launched', 12 Nov, 2020, <https://www.timesnownews.com/india/article/indian-navy-gets-fifth-scorpeneclass-submarine-ins-vagir/680844>; and Pubby, Manu, 'India's Rs 1.2 lakh crore nuclear submarine project closer to realisation', The Economic Times, 21 Feb. 2020, <https://economictimes.indiatimes. com/news/defence/indias-rs-1-2-1-cr-n-submarine-project-closer-to-realisation/articleshow/74234776. cms $>$.

14 Nair-Ghaswalla, Amrita, 'Six Indian Navy submarines to be upgraded', 7 Feb. 2018, <https://www. thehindubusinessline.com/news/six-indian-navy-submarines-to-be-upgraded/article22681899.ece>.

15 Press Trust of India, 'Submarines a priority over aircraft carriers for navy, says CDS Gen Bipin Rawat; announces plan to look at overseas bases for logistics', FirstPost, 17 Feb. 2020, <https://www. 
firstpost.com/india/submarines-a-priority-over-aircraft-carriers-for-navy-says-cds-gen-bipin-rawatannounces-plan-to-look-at-overseas-bases-for-logistics-8050811.html>.

16 Roche, Elizabeth, 'Chinese presence in the Indian Ocean may go deeper', Mint, 15 Apr. 2021, $<$ https://www.livemint.com/news/india/chinese-presence-in-indian-ocean-has-been-a-regularphenomenon-in-past-decade-11618407976324.html>; The Economic Times, 'Chinese naval might threatens Indian Ocean Region balance', <https://economictimes.indiatimes.com/news/defence/chinesenaval-might-threatens-indian-ocean-region-balance/threat-to-india/slideshow/77911724.cms>; The Economic Times, 'Chinese naval might threatens Indian Ocean Region balance', 3 Sep. 2020, <https:// theprint.in/opinion/india-has-a-bigger-worry-than-lac-china-now-expanding-military-footprint-in-indianocean/439934>.

17 Reuters, 'Pakistan fires "first submarine-launched nuclear-capable missile"', 9 Jan. 2017, <https:// www.reuters.com/article/us-pakistan-missiles-idUSKBN14T1EL>.

18 Panda, Ankit and Narang, Vipin, 'Pakistan Tests New Sub-Launched Nuclear-Capable Cruise Missile. What Now?', The Diplomat, 10 Jan. 2017, <https://thediplomat.com/2017/01/pakistans-testsnew-sub-launched-nuclear-capable-cruise-missile-what-now $>$.

19 Sutton, H.I., 'Pakistan's New Type-039B AIP Submarines: Image Shows Shipyard Expansion', Naval News, <https://www.navalnews.com/naval-news/2020/10/pakistans-new-chinese-aip-submarinesimage-shows-karachi-site>.

20 Khan, M. A., 'S-2: Options for the Pakistan Navy', Naval War College Review, vol. 63, no. 3, 2010, pp. 85-104.

21 These submarine manoeuvres occurred after allegedly Pakistan-trained terrorists attacked an Indian military convoy, which was followed by an Indian retaliatory strike against bases. ANI, 'Post-Balakot, Indian Navy hunted for Pakistani submarine for 21 days', Business Standard, 23 Jun. 2019, <https:// www.business-standard.com/article/news-ani/post-balakot-indian-navy-hunted-for-pakistani-submarinefor-21-days-119062300338_1.html>; and Som, Vishnu, 'India Deployed Nuclear Missile-Armed Submarine During Standoff With Pak', NDTV, 18 Mar. 2019, <https://www.ndtv.com/india-news/indiadeployed-nuclear-missile-armed-submarine-during-standoff-with-pakistan-2009178>.

22 Some examples include the USS James Madison incident in 1974, the Kildin Island incident in 1992 and the Kola peninsula incident in 1993.

23 As one example, during the Cold War, the Union of Soviet Socialist Republics and the United States both possessed submarines with nuclear weapons on board. In spite of tensions, they demonstrated the ability to ensure proper control over their storage and use. An example is the incident with the Soviet submarine B-29 in 1967, when the three keys rule prevented the launch of a torpedo with a nuclear warhead at American ships.

24 Zarar, Syed, 'Pakistan Gains VLF Technology to Communicate with Under Sea Submarines', ProPakistani, <https:/propakistani.pk/2016/11/17/pakistan-gains-vlf-technology-communicate-seasubmarines>, accessed on 20 Oct. 2021.

25 Press Trust of India, 'Submarines a priority over aircraft carriers for navy, says CDS Gen Bipin Rawat; announces plan to look at overseas bases for logistics', FirstPost, 17 Feb. 2020, <https://www. firstpost.com/india/submarines-a-priority-over-aircraft-carriers-for-navy-says-cds-gen-bipin-rawatannounces-plan-to-look-at-overseas-bases-for-logistics-8050811.html>; Brar, Adil, 'Djibouti story resembles Hambantota, has the same Chinese script', The Print, 14 Apr. 2021, <https://theprint.in/ opinion/djibouti-story-resembles-hambantota-has-the-same-chinese-script/639249>; and 'India Worried as China-Myanmar Ties Deepen', Mint, 20 Jan. 2020, <https://www.livemint.com/news/india/indiaworried-as-china-myanmar-deepen-ties-11579492745298.html>.

26 Dabas, Maninder, 'Here Is All You Should Know About "String of Pearls", China's Policy To Encircle India', IT, <https://www.indiatimes.com/news/india/here-is-all-you-should-know-about-stringof-pearls-china-s-policy-to-encircle-india-324315.html $>$.

27 LaGrone, Sam, 'Chinese Submarine Headed to Gulf of Aden For Counter Piracy Operations', USNI News, 30 Sep. 2014, <https://news.usni.org/2014/09/30/chinese-submarine-headed-gulf-aden-counterpiracy-operations>.

28 Woody, Christopher, 'India is shopping for submarines as China extends its reach into the Indian Ocean', Business Insider, 27 Jul. 2017, < https://www.businessinsider.com/india-to-buy-submarinesamid-china-naval-activity-in-the-indian-ocean-2017-7>.

29 Pubby, Manu, 'Chinese submarine movements in Indian Ocean down, Pakistan Navy remains choked in', The Economic Times, 25 Apr. 2019, <https://economictimes.indiatimes.com/news/ 
defence/indian-battle-ships-take-part-in-chinese-navys-biggest-fleet-review-pakistan-gives-it-a-miss/ articleshow/69019513.cms>.

30 AtomicArchive.com, 'Broken Arrows: Nuclear Weapons Accidents', <https://www.atomicarchive. com/almanac/broken-arrows/index.html>, accessed on 20 Oct. 2021.

31 AFP, China says virus pushing US ties to brink of "Cold War", The Times of India, 24 May 2020, $<$ https://timesofindia.indiatimes.com/world/china/us-china-nearing-brink-of-new-cold-war-chineseforeign-minister/articleshow/75938317.cms>.

32 Ayres, Alyssa, 'The U.S. Indo-Pacific Strategy Needs More Indian Ocean', Council on Foreign Relations, 22 Jan. 2019, <https://www.cfr.org/expert-brief/us-indo-pacific-strategy-needs-more-indianocean>. 